Uniwersytet Rolniczy

Płowdiw, Bułgaria

MILENA TEPAVICHAROVA

Wyższa Szkoła Bezpieczeństwa i Gospodarki

Płowdiw, Bułgaria

AGNIESZKA WRZOCHALSKA

Instytut Ekonomiki Rolnictwa i Gospodarki Żywnościowej

- Państwowy Instytut Badawczy

Warszawa, Polska

\title{
CHARAKTERYSTYKA I KIERUNKI ROZWOJU KOMPETENCJI ZAWODOWYCH KAPITAŁU LUDZKIEGO W SEKTORZE ROLNYM
}

\begin{abstract}
Abstrakt
W ostatnich latach rozwój kompetencji zawodowych jest coraz częściej zwiazany z wynikami i ocena kapitału ludzkiego oraz rozwojem kariery. Tworzenie kapitału ludzkiego wymaga działań skoncentrowanych na poprawie konkretnej wiedzy, konkretnych umiejętności i zdolności. Analiza stanu i kierunków rozwoju kompetencji zawodowych kapitału ludzkiego w sektorze rolnym Bułgarii ukazuje wiele możliwości jego skutecznego wykorzystania $i$ zarzadzania.

Niniejszy artykut ma na celu zidentyfikowanie kompetencji zawodowych kapitału ludzkiego w sektorze rolnym przez analize i prezentację kierunków jego rozwoju.

Praca obejmuje okres od stycznia do listopada 2015 r. Opiera się na danych zaczerpnietych $z$ ankiet specjalnie zaprojektowanych do tego celu oraz na bezpośrednich kontaktach, dokumentacji firmowej itd. Do sprecyzowania danych i informacji zastosowano metode wywiadu. Problemy i możliwości rozwoju kompetencji zawodowych kapitału ludzkiego w rolnictwie zaprezentowano i oceniono według otrzymanych odpowiedzi.
\end{abstract}

Słowa kluczowe: kompetencje zawodowe, kapitał ludzki, sektor rolny.

Kody JEL: A13, E24, J24. 


\section{Wstęp}

W ostatnich latach ze względu na zaawansowane technologie, globalizację i wydłużenie okresu aktywności zawodowej konieczne jest ciągłe dostosowywanie umiejętności osobistych i kompetencji zawodowych kapitału ludzkiego. Wiąże się to z licznymi zmianami i wyzwaniami w zakresie rozwoju zawodowego. Obecnie niezmiernie istotna staje się kwestia ustawicznego zarządzania karierą, która wymaga szerokiego zestawu umiejętności i rozległej wiedzy. Działania takie dają możliwość znalezienia zatrudnienia i dostosowania się do wykonywanej pracy oraz rozwoju osobistego, pozwalającego poradzić sobie z zadaniami zawodowymi i dającego satysfakcję z pracy oraz gwarantującego odpowiednie za nią wynagrodzenie.

Zdobywanie zestawu kompetencji wspierających wykorzystanie zasobów ludzkich w sektorze rolnym wymaga celowych działań ukierunkowanych na poprawę pewnych umiejętności i zdolności. Są one „,wspólnym językiem”, którym komunikują się pracodawcy i pracownicy, prezentującym jakość społeczną i orientację osobistą kapitału ludzkiego w gospodarstwach sektora rolnego. $\mathrm{W}$ miarę postępujących zmian w sektorze potrzeby w zakresie siły roboczej również zmieniają się i wzrastają.

W ostatnich latach rozwój kompetencji zawodowych w sektorze rolnym jest coraz częściej związany z wynikami i procesem oceny kapitału ludzkiego oraz rozwojem kariery. Zaawansowanie tych kompetencji wymaga celowego działania, mającego na celu poprawę pewnych obszarów wiedzy, umiejętności i zdolności. Analiza stanu i kierunków rozwoju kompetencji zawodowych kapitału ludzkiego w sektorze rolnym Bułgarii ukazuje wiele możliwości jego skutecznego wykorzystania i zarządzania.

Niniejszy artykuł ma na celu scharakteryzowanie kompetencji zawodowych kapitału ludzkiego w sektorze rolnym przez analizę i prezentację kierunków jego rozwoju.

\section{Materiały i metody}

Badanie obejmuje dwie grupy docelowe - pracodawców i pracowników. Dane z pierwszej grupy pozwalają na przeprowadzenie komparatywnej charakterystyki i prezentację kierunków rozwoju kompetencji zawodowych kapitału ludzkiego zarówno ogólnie w sektorze rolnym, jak i w jego podsektorach - uprawie roślin i hodowli zwierząt. Informacje na temat drugiej grupy umożliwiają porównanie wymogów stawianych przez pracodawców potencjalnym pracownikom zatrudnianym w gospodarstwach sektora rolnego.

Aby scharakteryzować kompetencje zawodowe, zbadano opinie właścicieli, zarządców i osób zawodowo zajmujących się zarządzaniem zasobami ludzkimi z 156 gospodarstw różniących się wielkością, statusem i tytułem własności w sektorze rolnym. Większość zbadanych gospodarstw znajduje się w regionie południowo-środkowym, gdzie na początku okresu objętego badaniem gospodarstwa stanowiły 27,76\% całkowitej liczby gospodarstw w kraju (MAF, 2015). 
W zależności od wielkości badane gospodarstwa są podzielone na cztery grup, a mianowicie:

- od 1 do 10 pracowników - 46,79\%;

- od 11 do 50 pracowników - 35,89\%;

- od 51 do 100 pracowników - 10,11\%;

- ponad 101 pracowników - 7,21\%.

Biorąc pod uwagę specyfikę procesu produkcji w gospodarstwach specjalizujących się w produkcji roślinnej i zwierzęcej, badanie jest prowadzone osobno dla tych dwóch sektorów.

Rozróżnienie gospodarstw na podstawie sektora opiera się na klasyfikacji gospodarstw według typów wyszczególnionych w badaniu struktury gospodarstw rolnych Eurostat 2007. Zakłada się, że charakter sektora gospodarstw rolnych określa większość produkcji (ponad 60\%).

Porównując znaczenie wiedzy i umiejętności mających znaczenie dla sukcesu zawodowego, przeanalizowaliśmy opinie przedstawicieli personelu kierowniczego badanych gospodarstw. W tym celu przeprowadziliśmy wywiady z 296 pracownikami i pracodawcami. Klasyfikacja uczestników zgodnie z różnymi kryteriami pokazuje ich szeroki przekrój (rys. 1).

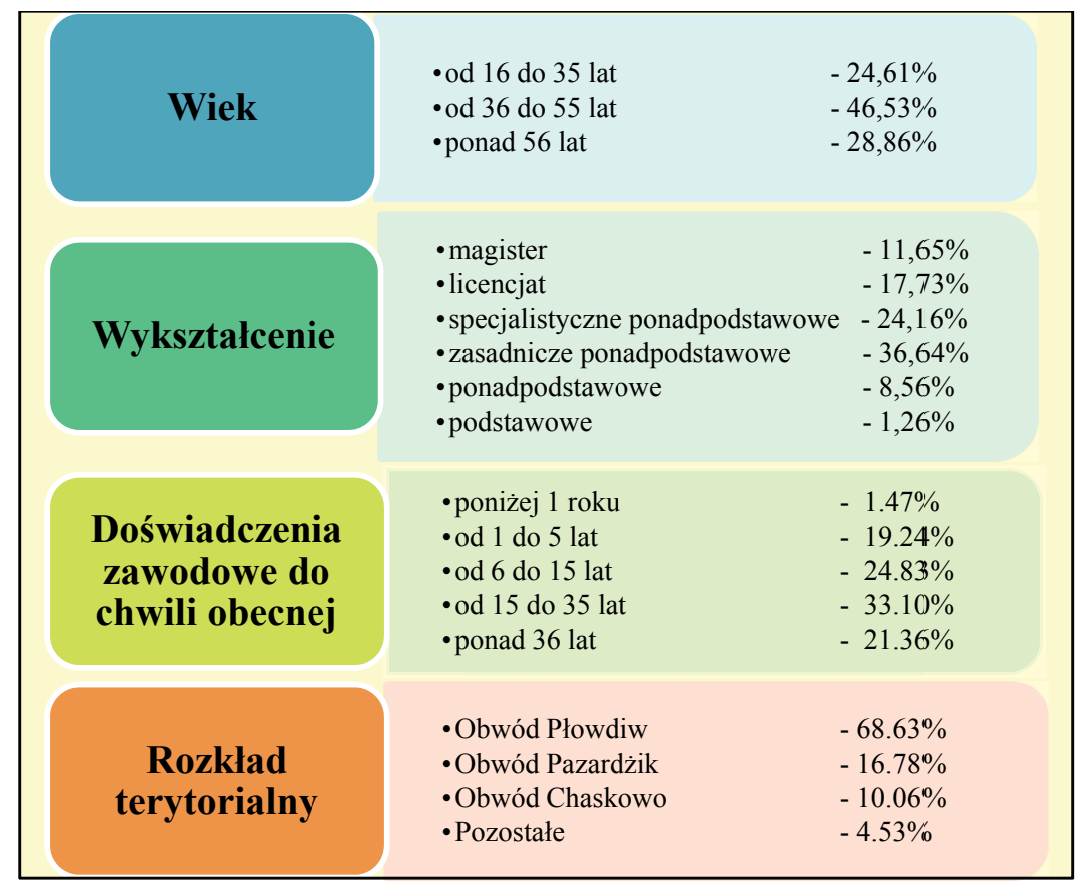

Rys. 1. Klasyfikacja uczestników zgodnie z różnymi kryteriami.

Źródło: Dane na podstawie opracowania własnego. 
Na potrzeby badania opracowano dwa rodzaje kwestionariuszy, osobno dla pracodawców i pracowników. Badanie skupiało się na pozyskaniu informacji na temat:

- najważniejszych kompetencji z perspektywy pracodawców przy zatrudnianiu nowych pracowników;

- poziomu tych umiejętności wśród pracowników w sektorze rolnym;

- poziomu posiadania przez absolwentów ze stopniem naukowym w naukach rolniczych koniecznych kompetencji zawodowych;

- momentu, kiedy należy zająć się budowaniem kompetencji zawodowych. Uczestnikom ankiet najpierw przedstawiliśmy listę 20 głównych grup kompetencji zawodowych, ich zwięzłych definicji i opisów (tab. 1). Respondenci zostali poproszeni o ich ocenę $\mathrm{w}$ pięciostopniowej skali, a mianowicie: 1 - nieważne, 2 - mniej ważne, 3 - ważne, 4 - bardzo ważne, 5 - niezmiernie ważne.

Faktyczna lista przygotowana na potrzeby badania uwzględnia następujące aspekty:

- kluczowe kompetencje opracowane przez Komisję Europejską (The Definition..., 2010);

- wstępne analizy podobnych badań w Europie i na świecie przeprowadzone w ostatnich latach (Employers' perception..., 2010; Ready to grow..., 2010; Graduate Employability..., 2008);

- przegląd najczęściej wspominanych umiejętności i cech charakterystycznych wymaganych od osób ubiegających się o pracę na podstawie ogłoszeń;

- konsultacje z pracodawcami, ekspertami w zakresie edukacji i doradcami, którzy pomogli podzielić umiejętności na 20 grup.

Praca obejmuje okres od stycznia do listopada 2015 r. Opiera się na danych zaczerpniętych $\mathrm{z}$ ankiet specjalnie zaprojektowanych do celu analizy oraz na bezpośrednich kontaktach, dokumentach firmowych itd. W celu sprecyzowania danych i informacji wykorzystaliśmy metodę wywiadu. Problemy i możliwości rozwoju kompetencji zawodowych kapitału ludzkiego w sektorze rolnym zaprezentowano i oceniono w oparciu o otrzymane odpowiedzi. 
Opis głównych grup kompetencji zawodowych

\begin{tabular}{|c|c|c|}
\hline Lp. & Kompetencja & Opis \\
\hline 1 & $\begin{array}{l}\text { Zdolność } \\
\text { do adaptacji }\end{array}$ & $\begin{array}{l}\text { Zdolność przystosowania się do kultury korporacyjnej, elastyczność, } \\
\text { szybkie rozpoznawanie potrzeb zmieniającego się otoczenia, } \\
\text { w tym zdolność do pracy pod presją czasu i na krótkie terminy. }\end{array}$ \\
\hline 2 & $\begin{array}{l}\text { Gotowość i chęć } \\
\text { do nauki }\end{array}$ & $\begin{array}{l}\text { Chłonność umysłu, ciekawość, chęć samodoskonalenia, dążenie } \\
\text { do uzyskiwania informacji zwrotnych i umiejętność ich odbioru. }\end{array}$ \\
\hline 3 & Lojalność & Postawa etyczna, szczerość i uczciwość. \\
\hline 4 & Skuteczność & $\begin{array}{l}\text { Umiejętność radzenia sobie z zadaniami pracowymi i uzyskiwania } \\
\text { dobrych wyników. }\end{array}$ \\
\hline 5 & $\begin{array}{l}\text { Umiejętność } \\
\text { obsługi komputera }\end{array}$ & $\begin{array}{l}\text { Umiejętność korzystania z edytora tekstu, arkuszy kalkulacyjnych } \\
\text { i aplikacji internetowych. }\end{array}$ \\
\hline 6 & $\begin{array}{l}\text { Zdolności } \\
\text { przywódcze }\end{array}$ & $\begin{array}{l}\text { Umiejętności planowania, zarządzania i motywowania ludzi, } \\
\text { umiejętność podejmowania decyzji, negocjacji itd. }\end{array}$ \\
\hline 7 & $\begin{array}{l}\text { Zdolności } \\
\text { matematyczne }\end{array}$ & Praca z liczbami, dokładność, umiejętności metodyczne, precyzja. \\
\hline 8 & $\begin{array}{l}\text { Umiejętność pracy } \\
\text { w zespole }\end{array}$ & $\begin{array}{l}\text { Współpraca, rozwiązywanie konfliktów, dobre relacje interpersonalne, } \\
\text { umiejętność budowania relacji. }\end{array}$ \\
\hline 9 & Motywacja & Pozytywne nastawienie do pracy, entuzjazm. \\
\hline 10 & $\begin{array}{l}\text { Kompetencje } \\
\text { zawodowe }\end{array}$ & $\begin{array}{l}\text { Konkretne umiejętności i wiedza na polu zawodowym, } \\
\text { odpowiednia koncepcja pracy. }\end{array}$ \\
\hline 11 & $\begin{array}{l}\text { Umiejętności } \\
\text { komunikacyjne }\end{array}$ & $\begin{array}{l}\text { Zrozumiały, przekonujący i kulturalny sposób wyrażania myśli } \\
\text { zarówno w słowie, jak i na piśmie. }\end{array}$ \\
\hline 12 & Postawa krytyczna & $\begin{array}{l}\text { Umiejętności analityczne, logicznego myślenia, obiektywność, } \\
\text { dokładność. }\end{array}$ \\
\hline 13 & $\begin{array}{l}\text { Umiejętności } \\
\text { biurowe }\end{array}$ & $\begin{array}{l}\text { Umiejętność wyszukiwania i organizowania informacji, dokumentów, } \\
\text { danych; dobra organizacja pracy i umiejętność korzystania } \\
\text { ze sprzętów biurowych. }\end{array}$ \\
\hline 14 & Przedsiębiorczość & $\begin{array}{l}\text { Inicjatywa, przedsiębiorczość, wiedza i intuicja biznesowa, } \\
\text { determinacja, umiejętność podejmowania decyzji i ryzyka. }\end{array}$ \\
\hline 15 & $\begin{array}{l}\text { Umiejętność } \\
\text { autoprezentacji }\end{array}$ & $\begin{array}{l}\text { Umiejętności w zakresie udanej prezentacji własnej osoby } \\
\text { (w tym w podaniu i rozmowie o pracę), pewność swoich umiejętności, } \\
\text { pozytywne nastawienie, pewność siebie, znajomość komunikacji } \\
\text { biznesowej. }\end{array}$ \\
\hline 16 & Kreatywność & Kreatywność, inicjatywa, pomysłowość, myślenie lateralne. \\
\hline 17 & $\begin{array}{l}\text { Umiejętności } \\
\text { techniczne }\end{array}$ & $\begin{array}{l}\text { Konkretne umiejętności pozwalające na korzystanie } \\
\text { ze specjalistycznego oprogramowania i sprzętu. }\end{array}$ \\
\hline 18 & $\begin{array}{l}\text { Podejście } \\
\text { do klienta }\end{array}$ & $\begin{array}{l}\text { Chęć współpracy, empatia, pozytywne nastawienie, takt, tolerancja, } \\
\text { cierpliwość, dbałość o klienta. }\end{array}$ \\
\hline 19 & $\begin{array}{l}\text { Umiejętność } \\
\text { samoorganizacji }\end{array}$ & $\begin{array}{l}\text { Odpowiedzialność, niezależność, dobra organizacja czasu pracy } \\
\text { i wykonywanych zadań. }\end{array}$ \\
\hline 20 & $\begin{array}{l}\text { Znajomość } \\
\text { języków obcych }\end{array}$ & $\begin{array}{l}\text { Znajomość języka obcego (w mowie i piśmie), międzykulturowe } \\
\text { doświadczenia i wiedza. }\end{array}$ \\
\hline
\end{tabular}

Źródło: Dane na podstawie opracowania własnego. 


\section{Wyniki i ich omówienie}

\section{Charakterystyka kompetencji zawodowych kapitału ludzkiego w gospodarstwach sektora rolnego}

Budowanie i doskonalenie kompetencji zawodowych staje się fundamentalną potrzebą ze względu na:

- trudności w realizacji zawodowej, które napotykają uczestnicy rynku pracy w latach przejściowych;

- powiększającą się lukę pomiędzy tradycyjnymi programami szkoleniowymi a obecnymi celami i potrzebami profesjonalistów w gospodarstwach sektora rolnego;

- gorsze niż spodziewane wyniki wielu reform instytucjonalnych, które w większości przypadków nie wpływają na zmiany w zasobach ludzkich.

Dane ankietowe zebrane od pracodawców pokazują, że żadna z 20 zaproponowanych kompetencji zawodowych nie została oceniona jako „nieważna”.

W sektorze uprawy roślin respondenci zidentyfikowali jako szczególnie istotne z perspektywy rozwoju zawodowego personelu: szkolenia zawodowe, umiejętność pracy w zespole, gotowość i chęć do nauki, zdolność do adaptacji, motywację, skuteczność i umiejętność samoorganizacji. Są one oceniane jako „bardzo ważne” przy zatrudnianiu nowych pracowników i mają ocenę od 4 powyżej (tab. 2).

Podobne opinie wyrażają pracodawcy w sektorze hodowli zwierząt gospodarskich. Wśród bardzo ważnych wymieniają oni następujące kompetencje zawodowe: szkolenia zawodowe, gotowość i chęć do nauki, umiejętność pracy w zespole, zdolność do adaptacji i umiejętność samoorganizacji. Jako szczególnie istotne w tym miejscu oceniane są również umiejętności komunikacyjne i umiejętności językowe.

Z przedstawionych danych można wywnioskować, że podobne wyniki są obserwowane w ocenie kompetencji zawodowych w obydwu podsektorach sektora rolnego. Większość pracodawców jako szczególnie istotne przy zatrudnianiu nowych pracowników wymienia: szkolenia zawodowe, zdolność do adaptacji, umiejętność pracy w zespole oraz gotowość i chęć do nauki. Pewne rozbieżności zostały zaobserwowane w zakresie umiejętności komunikacyjnych i językowych. Według opinii pracodawców sektora hodowli zwierząt aspekty te są „bardzo ważne”, natomiast w sektorze uprawy roślin zostały one ocenione tylko jako „ważne”.

Jako najmniej istotny aspekt przy zatrudnianiu pracodawcy sektora rolnego wskazują umiejętności techniczne i matematyczne. 
Tabela 2

Ocena znaczenia kompetencji zawodowych przy zatrudnianiu nowych pracowników według pracodawców

\begin{tabular}{|c|c|c|c|}
\hline \multirow{2}{*}{ Kompetencje zawodowe } & \multicolumn{3}{|c|}{ Sektory działalności } \\
\hline & Sektor rolny & Uprawa roślin & Hodowla zwierząt \\
\hline Umiejętności zawodowe & 4,69 & 4,67 & 4,71 \\
\hline Gotowość i chęć do nauki & 4,48 & 4,49 & 4,48 \\
\hline Umiejętność pracy w zespole & 4,53 & 4,44 & 4,62 \\
\hline Zdolność do adaptacji & 4,37 & 4,34 & 4,40 \\
\hline Umiejętność samoorganizacji & 4,27 & 4,18 & 4,36 \\
\hline Skuteczność & 4,02 & 4,16 & 3,89 \\
\hline Motywacja & 4,00 & 4,03 & 3,96 \\
\hline Umiejętności komunikacyjne & 4,10 & 3,96 & 4,24 \\
\hline Znajomość języków obcych & 3,87 & 3,66 & 4,08 \\
\hline Umiejętność autoprezentacji & 3,38 & 3,56 & 3,21 \\
\hline Umiejętność obsługi komputera & 3,58 & 3,55 & 3,62 \\
\hline Podejście do klienta & 3,21 & 3,36 & 3,55 \\
\hline Lojalność & 3,15 & 3,23 & 3,06 \\
\hline Umiejętności biurowe & 3,35 & 3,18 & 3,51 \\
\hline Kreatywność & 3,09 & 3,03 & 3,15 \\
\hline Postawa krytyczna & 2,83 & 2,72 & 2,94 \\
\hline Zdolności przywódcze & 2,75 & 2,71 & 2,78 \\
\hline Przedsiębiorczość & 2,65 & 2,70 & 2,61 \\
\hline Umiejętności techniczne & 2,47 & 2,37 & 2,56 \\
\hline Zdolności matematyczne & 2,38 & 2,23 & 2,53 \\
\hline Przepytani pracodawcy, \% & 100 & 68,5 & 31,5 \\
\hline
\end{tabular}

Źródło: Dane na podstawie opracowania własnego.

\section{Ocena znaczenia kompetencji zawodowych w opinii siły roboczej zatrudnionej w gospodarstwach sektora rolnego}

Ocena kompetencji zawodowych przez pracowników jest w znacznym stopniu zgodna z oceną pracodawców (tab. 3).

Respondenci z obydwu grup docelowych ocenili jako szczególnie istotne: szkolenia zawodowe, gotowość i chęć do nauki, umiejętność pracy w zespole, zdolność do adaptacji, skuteczność i motywację. Zbieżność stanowisk skłania do stwierdzenia, że pracownicy gospodarstw sektora rolnego są świadomi wielkiego znaczenia kompetencji zawodowych dla pracodawców. Może to w znacznym stopniu przyczynić się do ich udanej kariery zawodowej. 
Pewne sprzeczności zaobserwowano w ocenie przedsiębiorczości i zdolności przywódczych. Pracownicy uznają je za ważne, natomiast dla pracodawców nie są one szczególnie istotne. Z kolei pracodawcy szczególnie cenią umiejętności komunikacyjne i umiejętność pracy z klientem.

Tabela 3

Ocena znaczenia kompetencji zawodowych przez pracowników i pracodawców

\begin{tabular}{|c|c|c|}
\hline \multirow{2}{*}{ Kompetencje zawodowe } & \multicolumn{2}{|c|}{ Grupy docelowe } \\
\hline & Pracodawcy & Kadra kierownicza \\
\hline Umiejętności zawodowe & 4,69 & 4,53 \\
\hline Gotowość i chęć do nauki & 4,48 & 4,41 \\
\hline Umiejętność pracy w zespole & 4,53 & 4,40 \\
\hline Zdolność do adaptacji & 4,37 & 4,23 \\
\hline Umiejętność samoorganizacji & 4,27 & 3,97 \\
\hline Skuteczność & 4,02 & 4,11 \\
\hline Motywacja & 4,00 & 4,01 \\
\hline Umiejętności komunikacyjne & 4,10 & 3,24 \\
\hline Znajomość języków obcych & 3,87 & 3,96 \\
\hline Umiejętność autoprezentacji & 3,38 & 3,46 \\
\hline Umiejętność obsługi komputera & 3,58 & 3,23 \\
\hline Podejście do klienta & 3,21 & 2,69 \\
\hline Lojalność & 3,15 & 3,64 \\
\hline Umiejętności biurowe & 3,35 & 3,55 \\
\hline Kreatywność & 3,09 & 2,53 \\
\hline Postawa krytyczna & 2,83 & 2,36 \\
\hline Zdolności przywódcze & 2,75 & 3,12 \\
\hline Przedsiębiorczość & 2,65 & 3,10 \\
\hline Umiejętności techniczne & 2,47 & 2,17 \\
\hline Zdolności matematyczne & 2,38 & 2,14 \\
\hline Respondenci, liczba & 156 & 296 \\
\hline
\end{tabular}

Źródło: Dane na podstawie opracowania własnego.

\section{Ocena pozyskanych kompetencji zawodowych przez absolwentów ze stopniem naukowym}

W odniesieniu do oceny kompetencji pozyskanych przez absolwentów ze stopniem naukowym wyciągnięto następujące wnioski:

- Pracodawcy i pracownicy oceniają jako najbardziej istotne: gotowość i chęć do pracy, motywację, umiejętności komunikacyjne, umiejętności obsługi komputera i kreatywność (rys. 2 i 3 ). 


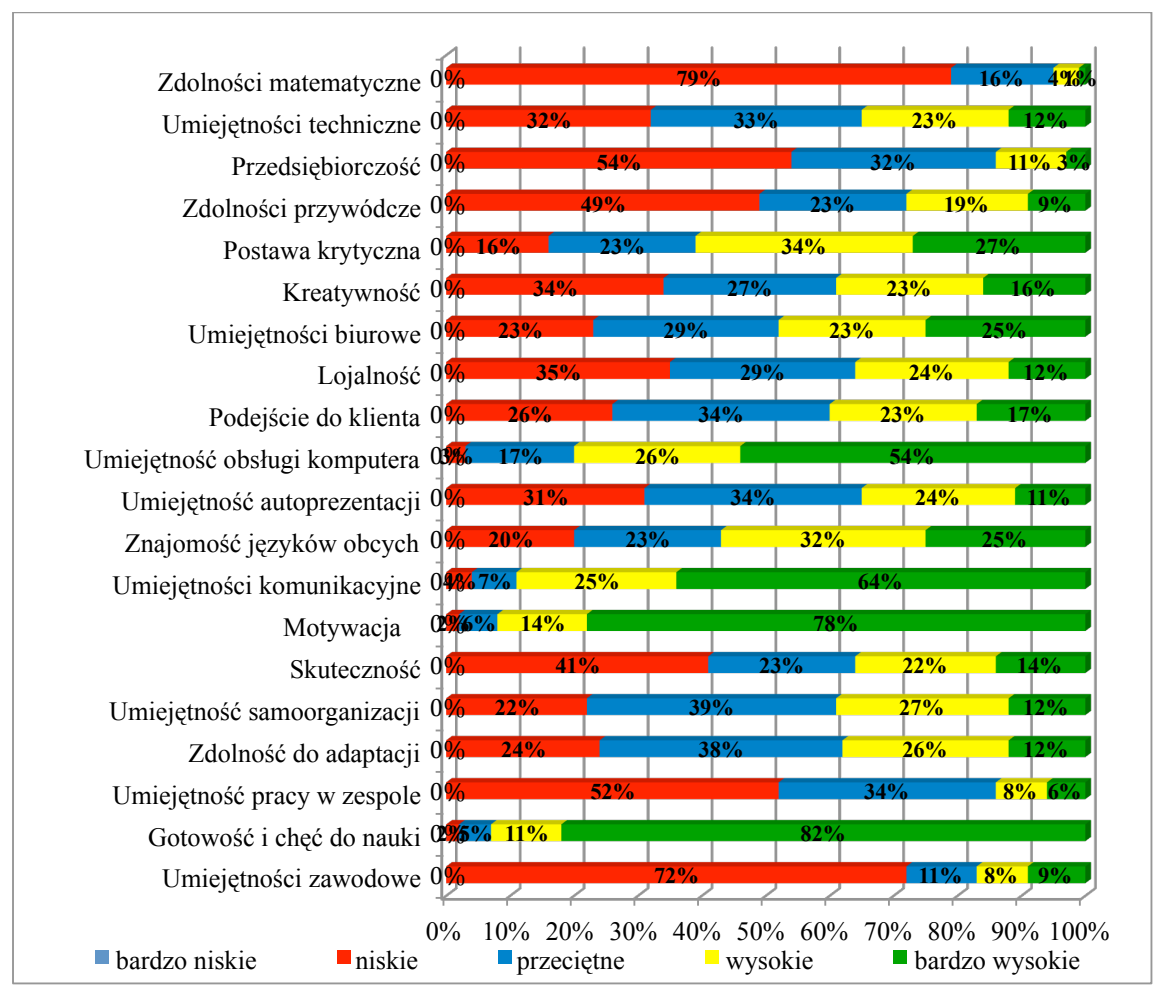

Rys. 2. Stopień pozyskanych kompetencji zawodowych absolwentów z tytułem naukowym w dziedzinie nauk rolniczych w opinii pracodawców.

Źródło: Dane na podstawie opracowania własnego.

- Do kompetencji zawodowych, które występują najrzadziej, pracownicy i pracodawcy zaliczają: umiejętności matematyczne, przedsiębiorczość, szkolenia zawodowe, zdolności przywódcze, umiejętności techniczne, myślenie krytyczne i umiejętności biurowe. Zbieżność postaw pokazuje, że obraz szans i luk w systemie edukacji jest przejrzysty. Jedną z alternatyw rozwoju i doskonalenia słabo rozwiniętych kompetencji zawodowych jest samokształcenie (Bencheva, Tepavicharova, 2011).

- Większość pracodawców ocenia jako względnie dobre umiejętności językowe absolwentów z pewnym stopniem naukowym w dziedzinie nauk rolniczych. Na ocenę tę ma pewien wpływ fakt, że znajomość języka obcego zaczyna być rozwijana w bardzo wczesnym wieku i jest kontynuowana przez cały okres nauki. Pracownicy gospodarstw sektora rolnego mają jednak całkiem odmienną opinię. Opisują oni umiejętności językowe absolwentów jako niezadawalające. Swoją opinię opierają na świadomości, że aby budować umiejętności i kompetencje językowe, należy aktywnie użytkować język, czego system edukacyjny nie jest w stanie zapewnić. 


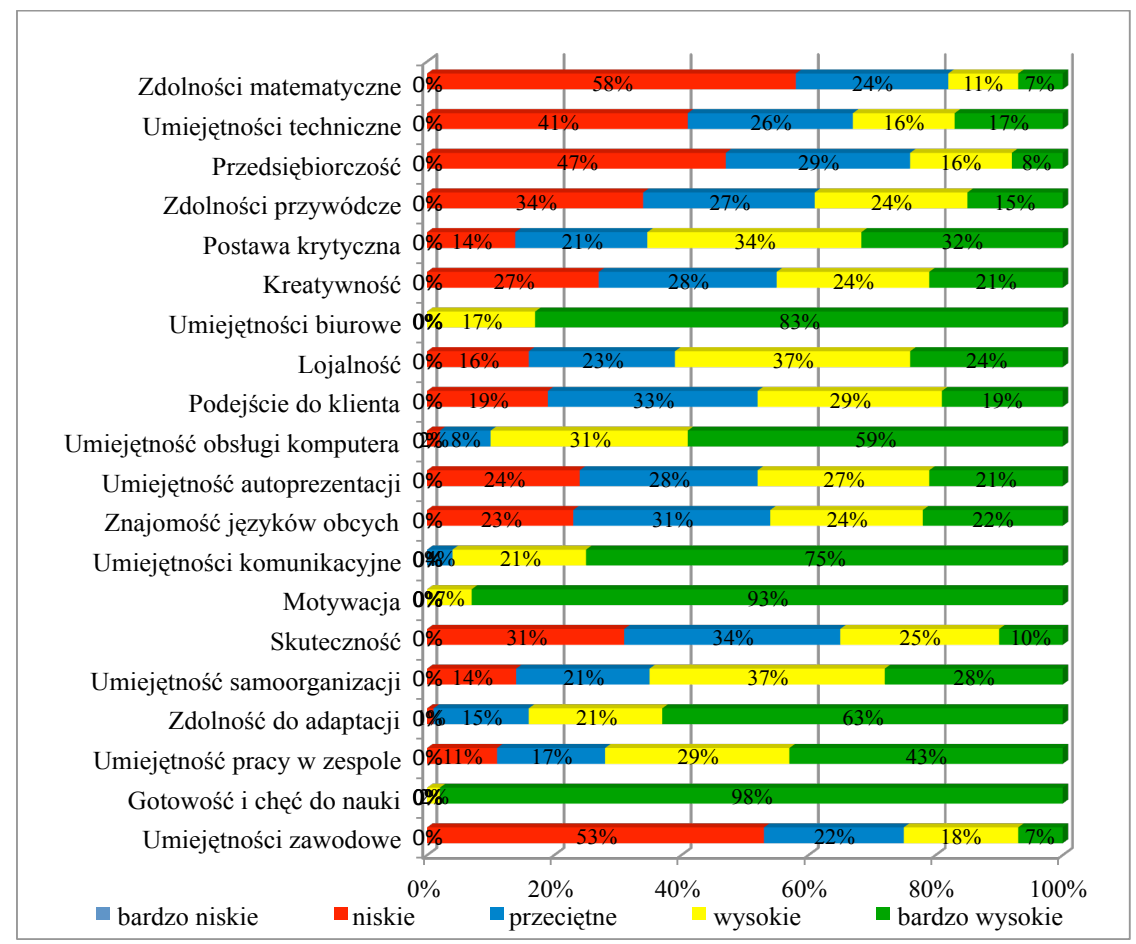

Rys. 3. Stopień zdobytych kompetencji zawodowych absolwentów z tytułem naukowym w dziedzinie nauk rolniczych w opinii pracowników.

Źródło: dane na podstawie opracowania własnego.

- Pewne rozbieżności w ocenie pracodawców i przepytanych pracowników zaobserwowano w kwestii zdolność do adaptacji, umiejętności pracy w zespole, umiejętności pracy z klientem i lojalności. W opinii pracodawców powyższe kompetencje są wykorzystywane w dużo mniejszym stopniu niż byłoby to pożądane. Pracownicy jednak są zdania, że osoby z wykształceniem wyższym i ponadpodstawowym $\mathrm{w}$ dziedzinie nauk rolniczych posiadają te kompetencje w stopniu znacznie wyższym niż prezentowali pracodawcy. Pokazuje to potrzebę ukierunkowanego i praktycznego zdobywania i doskonalenia odpowiednich umiejętności i kompetencji.

\section{Okres budowania kompetencji zawodowych}

W odniesieniu do okresu budowania kompetencji zawodowych w obydwu grupach docelowych najwyższy procent respondentów wskazał na szkołę wyższą (tab. 4). Zakłada się, że jest to okres pozyskiwania świadomości i podejmowania serii decyzji dotyczących kierunków rozwoju społecznego i osobistego człowieka. Może to pomóc w przejściu z systemu edukacji do pracy i rozwoju zawodowego. 
Tabela 4

Okres budowania kompetencji zawodowych

\begin{tabular}{lcc}
\hline \multirow{2}{*}{ Okres } & \multicolumn{2}{c}{ Grupa docelowe } \\
\cline { 2 - 3 } & 21 & Kadra kierownicza (\%) \\
\hline Wczesne dzieciństwo & 20 & 3 \\
Szkoła podstawowa & 16 & 7 \\
Szkoła ponadpodstawowa & 43 & 11 \\
Szkoła wyższa & 0 & 46 \\
Po zakończeniu szkoły & 0 & 9 \\
Uniwersytet & 156 & 24 \\
Respondenci, liczba & & 296 \\
Źródło: dane na podstawie opracowania własnego. &
\end{tabular}

Ostatnim momentem na zdobywanie kompetencji zawodowych w przypadku pracodawców jest szkoła wyższa. Większość z nich (57\%) wskazuje poprzednie okresy, a $21 \%$ jest zdania, że zdobywanie kompetencji należy rozpocząć we wczesnym dzieciństwie. Pracodawcy uważają budowanie kompetencji zawodowych za inwestycję długoterminową, natomiast pracownicy sektora rolnego łączą ów proces z konkretnymi okresami przejściowymi w ich życiu. Według nich czas na rozwój wiedzy zawodowej i umiejętności powinien rozpoczynać się dużo później. Wśród respondentów $24 \%$ wyraziło opinię, że powyższe kompetencje powinny być budowane po ukończeniu szkoły i uniwersytetu.

\section{Podsumowanie}

Zdobywanie zestawu kompetencji wspierających adaptację pracowników gospodarstw w sektorze rolnym wymaga celowych działań mających na celu poprawę pewnych umiejętności i zdolności. Stanowią one kluczowy element przejścia od szansy na pracę do możliwości rozwoju zawodowego.

Umiejętności zawodowe to nie osobny zestaw umiejętności potrzebnych do przejścia z systemu edukacji do zatrudnienia, a połączenie wiedzy i umiejętności w zakresie zarządzania karierą, które trzeba budować od wczesnego wieku. Ich rozwój i doskonalenie ma ogromne znaczenie dla udanej kariery pracowników gospodarstw sektora rolnego.

Bez wątpienia ważną częścią tego procesu jest rozwój odpowiednich mechanizmów pozwalających zmniejszyć dystans pomiędzy systemem edukacji a wymogami dotyczącymi udanego rozwoju zawodowego potencjału ludzkiego gospodarstw sektora rolnego. Angażowanie pracodawców w opracowywanie programów szkoleniowych zorientowanych na rozwój kompetencji, doradztwo zawodowe i wspólne programy szkoleniowe dla stażystów to tylko kilka z działań, które mogą zostać rozpoczęte. 


\section{Literatura:}

Bencheva, N., Tepavicharova, M. (2011). Autodidactic instruments for increasing the expertise of managers and staff. National Conference "Learning from the crisis - lessons learned, recommendations and strategies", CEA, 13 May 2011, Plovdiv, s. 155-167.

CIPD. Competency and Competency Framework Survey. Latest version April 2007.

Dubois, D., Rothwell, W. (2004). Competency-Based Human Resource Management. Davies - Black Publishing.

Employers' perception of graduate employability (2010). Flash Euro barometer. Pobrane z: http://ec.europa.eu/public_opinion/flash/fl_304_en.pdf.

Graduate Employability: What do employers think and want? (2008). Pobrane z: http:// ec.europa.eu/education/higher-education/doc/business/graduate_en.pdf.

Lisbon Council - „Europe 2020: Why Skills are Key for Europe’s Future”. Pobrane z: http:// www.lisboncouncil,net/publication/publication/54-skillseuroprsfuture.html.

MAF (2015). Agrostatistics, Structure of the Agricultural Holdings.

Project „Development and implementation of an information system to evaluate the competence of the workforce in sectors and regions". Concept for the establishment of a national reference network.

Ready to grow: business priorities for education and skills. Education and skills survey (2010). Pobrane z: http://www.cbi.org.uk/ndbs/content.nsf/802737AED3E3420580256 706005390AE/C4393B860D00478E802576C6003B0679.

Study of professional competencies of human capital in the agricultural sector. January-November 2015.

The Definition and Selection of Key Competencies (2010). Pobrane z: http://www.oecd.org/ dataoecd/47/61/35070367.pdf. 
NELLY BENCHEVA

Agricultural University

Plovdiv, Bulgaria

MILENA TEPAVICHAROVA

Higher School of Security and Economy

Plovdiv, Bulgaria

AGNIESZKA WRZOCHALSKA

Institute of Agricultural and Food Economics -

National Research Institute

Warsaw, Poland

\title{
CHARACTERISTICS AND TRENDS IN THE DEVELOPMENT OF PROFESSIONAL COMPETENCE OF THE HUMAN CAPITAL IN THE AGRICULTURAL SECTOR
}

\begin{abstract}
During recent years, the development of professional competencies is more frequently linked with the processes of performance, evaluation and career development of the human capital. Their formation requires focused actions to improve particular knowledge, skills and abilities. The analysis of the status and trends in the professional competences of the human capital in the agricultural sector in Bulgaria reveals a number of opportunities for their effective use and management.

The purpose of this article is to outline the professional competences of the human capital in the agricultural sector by analysing and presenting the trends in their development.

The study covers the period between January and November 2015. It is based on data from polls specially designed for the purpose of the analysis, direct contacts, corporate documentation, etc. The interviews are applied to specify the data and information. The issues and prospects for the development of professional competences of the human capital in agriculture are presented and rated according to the responses received.
\end{abstract}

Keywords: professional competences, human capital, agricultural sector.

Zaakceptowano do druku - Accepted for print: 16.03.2017.

O ile nie jest to stwierdzone inaczej, wszystkie materiały na stronie są dostępne na licencji Creative Commons Uznanie Autorstwa 3.0 Polska. Pewne prawa zastrzeżone na rzecz Instytutu Ekonomiki Rolnictwa i Gospodarki Żywnościowej - PIB.

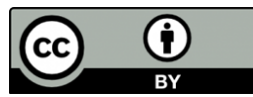

